\title{
On E Times Group Real Estate Development Company's Financial Management
}

\author{
Hui ping Huang ${ }^{1, a}$ and Hui min Huang ${ }^{2, b}$ \\ ${ }^{1}$ Zao Zhuang College, Shan dong Province 277160, China; \\ ${ }^{2}$ Bing Tuan College, Xin Jiang 831300, China. \\ axjhhp@126.com, ${ }^{\mathrm{b}} 471134372 @ q q . c o m$
}

Keywords: E Times; Group Real Estate Development Company; Financial Management; Information Technology.

\begin{abstract}
The aim of this study is to present financial management information system construction of a group of real estate enterprises in the Internet age or e era. This article analyzes development problems of group real estate: financing; cost control; bad real-time information and financial risks. Problems of current group real estate development enterprises are also discussed in the financial information system applications: lack of good architecture; low level of financial management systems; management inadequate attention. We present recommendations as the following: to create a good framework; to improve the level of financial management information. Among them, to create a good frame includes rationalizing enterprise data stream and unified information resource planning. To improve the level of financial management information can be divided into enhancing the level of financial risk control and referencing ERP information system to enhance the management level. It is necessary to financial management for group of real estate enterprise.
\end{abstract}

\section{Introduction}

With the rapid development of network information technology, the global real estate industries also begin a profound change. One is that intelligent residential quarters start to enter the lives of ordinary people; the other is that the real estate businesses are more prominent in the Information Age. The real estate industries have some of the characteristics of features, such as capital-intensive, high-risk, wide covers, and the strong influence by policy, long investment cycle, and slow return of funds, big business risk and other features. Real estate companies generally have a greater demand for funds, the need to banks, non-bank financial institutions and other companies. China's real estate is still not up to standard and the financial system is imperfect. The development of the Group's real estate enterprises is facing unprecedented opportunities and challenges in the era of e. The key to success is management, and financial management is the core of enterprise management. Therefore, to achieve the sound development of the real estate business, to obtain sustainable management, to develop core competitiveness, we must improve financial management of enterprises and strengthen company's financial management and control. As the group of real estate bigger enterprise business development and information management needs, the traditional financial management information system must be updated. To achieve financial business integration is the most important of information construction of a group of real estate enterprise.

\section{In the Form and Problems of Real Estate Companies}

\subsection{Development in the form of real estate development.}

Some people call it the 21st century information age, or the Internet age. It will be referred to as e era more image and representatives. With the rapid development of network information technology, the global real estate industry has also started a profound transformation. One is a smart residential district entered the lives of ordinary people; the other is that characteristic of the way of the real estate business is more prominent in the information age [1]. In recent years, as one of the main driving force of economic growth, China's residential real estate industry substantially boost with a annual 
economic growth, and investment is also on the rise. In particular, a series of the national policy in the real estate industry further determine pillar position and role of the real estate in the national economy. Face of e-era, the development of the Group real estate enterprises are facing unprecedented opportunities and challenges. Management is the key to success, and financial management is the core of enterprise management.

\subsection{Development problems of group real estate.}

1) Financing: It is difficult to finance for corporate. Sources channels of funding are for a single, higher risk. In the real estate development process, expensive land and construction project require a lot of financial support. Real estate project is a long cycle, high-risk, capital-intensive industry. Enterprise capital turnover rate is relatively and the recovery of funds is slow. They are facing serious financial risks, mainly in the debt risk,, interest-rate risk and refinancing risk. Once the capital strand breaks or risks a crisis, which no doubt will bring serious losses [2].

2) Cost control: Enterprises control cost inadequate and ignore comprehensive cost management. Real estate development is a complicated systematic project, including a number of links of financing, approval, construction and sales. It is high difficulty to cost control, especially for financial management and budget control. Comprehensive cost management requires of real estate development enterprise of the whole process, all-round, multi-level, full participation in the management of costs. But companies often ignore unity of the project planning, planning, design, construction, marketing aspects. Some managers simply consider cost management is the responsibility of the finance department, ignoring the importance of the whole process of cost accounting. This led to the financial sector the collection of information is not complete, resulting in cost management a far cry from the budget, losing effective control of costs. Overall cost management is a full, the whole process and comprehensive cost management. Cost of real estate development enterprises is a process, including the development of all aspects of pre-planning, planning, design, construction, sales. Cost management is throughout the project development process for planning, control of each element and maximizes corporate profits. Basic information of Real estate project cost management is from the various departments and enterprise management of the construction line. Some real estate development enterprises managers believe costing and management is the responsibility of the finance department, ignoring the internal functions throughout the production important role in the process of cost accounting. The financial sector is very limited to collecting the cost information, due to the deviation from the budgetary target cost management, which can not achieve effective cost control.

3) Bad real-time information: Currently the group real estate companies have launched a financial accounting and improve efficiency financial management. But there is also a common flaw, which is just a simple imitation and copy manual processes. It is a relatively independent work to move on the computer and through relatively independent subsystems (such as payroll management system, fixed assets accounting system) complete its work. It reflects cash flow information which is often lagging logistics information, the lack of real-time billing data. In a rapidly changing economic environment, real-time information determines its usefulness and control efforts. When an over-standard procurement cost or illegal events occur that capital flow accounting information can not be strictly controlled operation [3].

4) Financial risks: Real estate development business as a typical capital-intensive industry, with a lot of capital investment, long payback period, poor mobility characteristics, which determine the real estate development enterprises will face severe financial risk situation [4]. Most real estate development enterprises is financing through its funds, bank loans and debt management. Once a company has failed to effectively predict and control risk, they can not pay on time due bank loan principal and interest. The probability of occurrence of this risk is very great. The impact on the real estate debt management of development business for interest rate volatility is very large. If the asset-liability ratio is too high, the solvency of enterprises will be reduced. The credit of creditors the will be reduced, which is bound to increase the difficulty of corporate finance from money market funds or other sources. 


\subsection{The development direction of the group of real estate.}

With Group real estate Company development, management needs of information and expectations occur to changes and traditional financial management information system must be updated. Financial business integration is the most critical issues of a group of real estate development enterprise in information construction. How to achieve financial business integration is to achieve a truly effective control of business operations, to achieve a high degree of information integration.

\section{Problems of Current Group Real Estate Development Enterprises in the Financial Information System Applications}

Real estate development enterprise financial management means to forecast, plan, control, analysis and evaluate in a variety of funds, use, consumption, income distribution, as well as dealing with economic management of various financial relationships. This is an important part of corporate management. Financial management of real estate development enterprise is the enterprise funds, capital flows, including access to financing, use, consumption, income and distribution. They reflect the production obtained in the form, human and material resource consumption, production fruit distribution [5].

\subsection{Lack of good architecture.}

Head office and parent company between the financial system and between the financial system and the business system, is the lack of good framework. The independent system among each other to form "islands of information", the financial data can not form a connection and unable to fully share information. Although the advanced financial systems, but by doing statistical data and preparing financial statements.

\subsection{Low level of financial management systems.}

Modern financial information system is to make the financial work to do advance planning, things in control and after analysis and evaluation. The current financial management still remains only in hindsight accounting level, no matter good preparation and tracking control, predictive control serious shortcomings. Real estate Development Company's financial management is not to form a more perfect system and the management system is not perfect. Under the new economic situation, the financial management of some real estate development enterprises is still relatively traditional management relative chaos. In the financial management process it does not form a good management system, resulting in low efficiency of the financial management of real estate development companies, thus resulting in low economic efficiency of real estate development enterprises. Financial management information in the Group financial management can not form a highly integrated and share information platform. All management and business process convergence is not in place, which resulting in a variety of information needs can not be met. Meanwhile, the lack of effective budget management, real-time monitoring, analysis and reporting mechanisms and the lack of effective integration of the various systems of information and analysis, which makes information overload, decision value greatly reduces.

\subsection{Management inadequate attention: lack of security.}

Financial management level of real estate development enterprise is uneven and the overall quality is not high. On the one hand, in the financial management process of real estate development companies, many financial officers are affected the impact of the traditional management model and ideas, and do not use of advanced management methods, so that the financial management of real estate is at a low level and the type of management mode is also lagging behind. On the other hand, many real estate companies have not given the financial management sufficient attention so that financial management is not enough and in the enterprise development plan has not been scientifically positioning. Establishment of financial information system is a complex integrated system which requires leadership participation and support, but also real estate and business philosophy, business 
model and the way financial operations are closely related. This requires leadership driving, system assurance, and full company working together to complete.

\section{Group Real Estate Enterprise Information Technology of Financial Management}

\subsection{To create a good framework.}

1) Rationalizing enterprise data stream: Implementation of information system is built on the basis of complete data. On the basis of scientific data management is the key to the successful operation of information systems. Financial management information, as a strict information system, complete and accurate data processing of business aspects is the foundation of ensuring data accuracy, timeliness and reliability. Streamline data flow is one of the elements of a successful enterprise information construction. Advanced enterprise management concepts were integrated into enterprise management. In the process it will ultimately achieve scientific management in financial, logistics, business processes, cost accounting, customer relationship management and supply chain management. Therefore, it will be defined which data must be reported to business leaders, between a subsidiary and the parent company which data to be exchanged, which sectors need to access external knowledge or information, which needs to publicize and what data needs to confidentiality. When the data stream straightens out, the appropriate business management process also simplifies.

2) Unified information resource planning: To establish coordination mechanisms of information resources, overall plan and unified deploy. It should be established coordinated sustainable development goals to change the judicial division's phenomenon of fragmentation. This will help to avoid low-level redundant construction of information resources and the efficiency of development issues. It will help decision-makers to analysis the external environment of the system, grasp the direction and goals from the global information resources construction and use of effective means of configuration information resource. This will make it reasonable in time, spatial distribution. Through developing the strategic objectives of information, priorities and strategies, coordinating the economy activities of the various sectors, achieve organizational objectives the efficient operation and long-term planning goals.

Through the integrated platform application for system integration: Integrated platform can adapt that differentinformation systems share a common tool. Through enterprise application integration technology, business processes, public data, application software, hardware, and various criteria can be linked. Applications systems of different enterprise can integrate and agglomerate up together, so that they look like a whole processing business and sharing information. When between multiple enterprise systems for business transactions, integrated platform can achieve for system integration between different enterprises. Wealth coordination office platform technology use handwritten marking to ensure the seriousness and authority of OA Cooperative Office. It supports matrix management model, combined with "information net", "business associate" and "as needed but should be" three management philosophy. People break various barriers and border financial, material, information, processes and other resources between the various types of resources. By the greatest degree of coordination, development, utilization and value-added, it will fully achieve common goals, to achieve internal organization of business configuration. From the perspective of overall optimization of resources consider funds, equipment, technology, personnel, information and other elements of investment in order to achieve low-input and sustainable use of high efficiency. We should conduct a comprehensive transformation of existing systems. From the planning, through a unified information technology planning, ensures the uniform standard of information. This will meet the information needs and has laid a good foundation for the future new system. We should ensure that the new system follows the implementation of uniform standards, in order to achieve integration and information sharing system, thus avoiding the emergence of new information silos.

\subsection{To improve the level of financial management information.}

1) Strengthen the financial risk control: Internet information in a complex environment, the operating environment of market has become complex. Enterprises face unknowns gradually 
increasing, thereby increasing the risk of financial management. A large number of financial instruments increase in the corporate finance and investment channels, but bringing a lot of unknown's risk. Coupled with the advent of knowledge economy, greatly reducing the product life cycle, both to increase the risk of corporate deposits loans and increases the risk of product development. Therefore, in the context of information technology, enterprises should also strengthen financial risk control measures. Based on the establishment of risk prevention system, as the financial information management a template, enterprises should add financial risk defense sector in order to improve risk control.

2) References ERP information system to enhance the management level: Not only can some financial management software, but also some advanced information management technology enhance their financial management. For example, increasingly sophisticated ERP system is a good tool. It belongs to highly integrated management information software. Its information is more standardized, and more sophisticated, processing procedures and management information from a unified database. You can solve the problem of information silos within the enterprise. At the same time it can not occur to conflict under the premise of leaving the system crashes and use the good integration in other management software of enterprises. Especially after the integration with other systems, the sensitivity and accuracy of information processing will increase significantly. It can share financial data, remotely manage financial data and a number of summary information to satisfy decentralized or centralized financial management.

\section{Conclusion}

In recent years, the rapid development of China's real estate industry, real estate development enterprises in the number continued to increase. In an increasingly competitive situation, the real estate development business model of development has been gradually transferred to the fine management. Competition among enterprises is not only the capital, scale on competition, but also the competition management, management innovation. Financial management information is innovative and modern tools for financial management. It is the independence on the data and functional dependence between accounting information and it, which is in place on the control and decision throughout the enterprise information. Meticulous management is inseparable from the financial systems. Financial systems and project management systems are the two components of information technology of the real estate business [6]. Building a reasonable financial information system, not only can save a lot of labor costs, but also achieve information sharing, information integration and improve work efficiency. It not only can provide decision support for management, but also strengthen financial supervision, reduce operational risks and enhance their overall competitiveness.

\section{References}

[1]. Nianzhen Zhang, "Study to problems and countermeasures of financial management information of Group’s enterprises in China”. Taiyuan University of Technology, 2013, pp.5-6. (In Chinese).

[2]. Lijuan Sa, "On financial management and cost control of the business of real estate development”. Modern Marketing, 2012, pp.15-16. (In Chinese).

[3]. XueJing Qin, "several issues of real estate development enterprise financial management”. Financial Times, 2013, pp.21-23. (In Chinese).

[4]. Rui Zhou and Guangqi Ma, "Financial management research of estate development enterprise”. Chinese market, 2014, pp.33-35. (In Chinese).

[5]. Guorong Zhu, “On how to build financial management system of real estate business”. Financial supervision, 2012, pp.25-26. (In Chinese). 
[6]. Chun er Li, “On financial management practices of real estate development enterprise”. China Township Enterprises Accounting, 2013, pp.17-18. (In Chinese). 